\title{
Permanent up-regulation of regulatory T-lymphocytes in patients with head and neck cancer
}

\author{
ANNE K. SCHOTT* ${ }^{*}$, RALPH PRIES* and BARBARA WOLLENBERG \\ Department of Otorhinolaryngology, University of Schleswig-Holstein Campus Lübeck, D-23538 Lübeck, Germany
}

Received December 3, 2009; Accepted January 26, 2010

DOI: 10.3892/ijmm_00000436

\begin{abstract}
Various immune functions of different types of immune cells are strongly impaired in patients with head and neck squamous cell carcinoma (HNSCC). Regulatory T-lymphocyte cells (Tregs) have been suggested to be involved in the immunomodulation of immune responses and contribute to HNSCC progression and immune escape. 'Naturally' occurring $\mathrm{CD} 4{ }^{+} \mathrm{CD} 25^{+}$Tregs represent a small fraction within the different subsets of regulatory $\mathrm{T}$ cells, which are known to inhibit numerous immune functions of different types of immune cells. In this study, the cellular ratio of $\mathrm{CD} 4{ }^{+} \mathrm{CD} 25^{\text {high }}$ Tregs to the entire population of $\mathrm{CD}^{+} \mathrm{T}$-lymphocytes was analyzed with respect to different stages of tumor progression and disease. Our data indicate a significantly high increased abundance of $\mathrm{CD} 4{ }^{+} \mathrm{CD} 25^{\text {high }} \mathrm{CD} 127^{\text {low }}$ Tregs in the peripheral blood of patients with HNSCC, which in addition show modulated expression levels of various functional proteins. Surprisingly, increased Treg levels were found even in patients with no active disease several years after tumor resection, with no significant correlation to the individual tumor stage. Additionally, increased levels of chemokine CCL22, which mediates migration of Tregs to the tumor, and upregulation of the corresponding receptor protein CCR4 were observed in HNSCC. Our data strongly suggest that HNSCC leads to a permanent shift of Treg levels with hardly recognizable recovery rates.
\end{abstract}

\section{Introduction}

Head and neck squamous cell carcinoma (HNSCC) is one of the most common tumors and standard treatment has only slightly improved the 5-year survival rate of patients with HNSCC over the last 40 years (1-6).

Different studies have shown that the HNSCC microenvironment strongly impairs different types of immune cells

Correspondence to: Dr Barbara Wollenberg, UK-SH, Klinik für HNO, Ratzeburger Allee 160, D-23538 Lübeck, Germany

E-mail: barbara.wollenberg@uk-sh.de

*Contributed equally

Key words: head and neck cancer, T-lymphocyte cells, immunomodulation such as natural killer (NK) cells (7), monocytes (8) and T-lymphocytes (9). It has been suggested that regulatory T-lymphocytes (Tregs) play an important role in the suppression of anti-tumor immune responses and thus strongly participate in the immune escape process (10-19).

Tregs are divided into several subtypes, the so called 'naturally' occurring $\mathrm{CD} 4{ }^{+} \mathrm{CD} 25^{+}$Tregs and 'induced' or 'adaptive' Tregs, all of which are different in development, phenotype, cytokine secretion and immune function $(20,21)$. Naturally occurring CD4+ ${ }^{+}$Tregs constitute a small fraction of the overall $\mathrm{CD}^{+} \mathrm{T}$ cell population and constitutively coexpress CD25, a high affinity IL-2 receptor $\alpha$-subunit, on a high level (CD25 $\left.{ }^{\text {high }}\right)(22)$.

Natural $C D 4+C D 25^{\text {high }}$ Tregs arise in the thymus as a subpopulation of T-lymphocytes by the escape from apoptotic death during negative selection (23) and high-avidity interactions of their $\mathrm{T}$ cell receptors with self-peptides presented by MHC class II molecules expressed on thymic stroma cells $(24,25)$. Tregs appear to inhibit a variety of immune functions, such as the proliferation and cytokine secretion of $\mathrm{CD} 4^{+} \mathrm{T}$ cells as well as the lytic granule release by $\mathrm{CD}^{+}$effector cells $(12,26)$. Moreover, Tregs modulate the function and maturation of dendritic cells, monocytes and B-lymphocytes and the cytotoxic effects of NK cells $(12,27,28)$. Besides playing an important role in the regulation of immunotolerance and the prevention of autoimmune diseases (29), elevated proportions of regulatory $\mathrm{T}$ cells were found in different types of cancers, such as lung, breast (30), prostate cancer (31) and B-cell non Hodgkin lymphoma (32), and also in HNSCC (33). Furthermore, Tregs have been shown to be associated with a reduced survival in patients with ovarian carcinoma (34).

It has been suggested, that tumor-related factors induce and expand the accumulation of regulatory $\mathrm{T}$ cells in cancerbearing hosts (35). According to Curiel et al (34), ovarian tumor cells and microenvironmental macrophages produce CCL22/macrophage derived chemokine (MDC), a chemokine that induces the migration of regulatory $\mathrm{T}$ cells through corresponding CCL22 chemokine receptor CCR4 to tumor sites and impair anti-tumor immune responses.

Recent studies have suggested that $\mathrm{CD} 4{ }^{+} \mathrm{CD} 25^{+} \mathrm{T}$ cells are subdivided into suppressive $\mathrm{CD} 4{ }^{+} \mathrm{CD} 25^{\text {high }}$ Treg cells as well as $\mathrm{CD} 4{ }^{+} \mathrm{CD} 25^{\text {low }} \mathrm{T}$ cells, which are non-suppressive, antigenexperienced activated $\mathrm{CD} 4^{+} \mathrm{T}$ cells (36). In addition, the $\alpha$-chain of the IL-7 receptor (CD127) is supposed to be a specific marker protein for suppressive Tregs, namely $\mathrm{CD} 4+\mathrm{CD} 25^{\text {high }}$ CD127 ${ }^{\text {low }}$ (37). It was recently demonstrated that Tregs are 
Table I. Clinicopathologic features (sex, age, tumor site, TNM-stage, post-surgery since) of patients with HNSCC included in the study.

A, Sixteen presurgery patients with active disease characterized by sex, age, tumor site and TNM-stage

\begin{tabular}{|c|c|c|c|c|}
\hline Sample no. & Sex & Age & Tumor site & TNM-stage \\
\hline TB479 & $\mathrm{m}$ & 43 & epipharynx & $\mathrm{cT} 4 \mathrm{bcN} 3 \mathrm{cM} 0$ \\
\hline TB527 & $\mathrm{f}$ & 66 & oropharynx (relapse) & pT3N0cM0 \\
\hline TB530 & $\mathrm{m}$ & 49 & hypopharynx (relapse) & pT3pN2bcM0 \\
\hline TB533 & $\mathrm{m}$ & 55 & hypopharynx/larynx & pT4apN1cM1 \\
\hline TB534 & $\mathrm{m}$ & 69 & hypopharynx/larynx & cT3-4cN2ccM1 \\
\hline TB535 & $\mathrm{m}$ & 76 & larynx $\quad$ (relapse) & pT3pN0cMx \\
\hline TB536 & $\mathrm{m}$ & 71 & oropharynx & $\mathrm{cT} 3 \mathrm{cN} 2 \mathrm{acM} 0$ \\
\hline TB537 & $\mathrm{m}$ & 64 & larynx/hypopharynx & pT4pN2bcM0 \\
\hline TB538 & $\mathrm{f}$ & 57 & hypopharynx & cT4acN2ccM1 \\
\hline TB539 & $\mathrm{m}$ & 81 & oral cavity & cT3cN2cM0 \\
\hline TB541 & $\mathrm{m}$ & 56 & vocal cord right & pT2cN0cM0 \\
\hline \multirow[t]{2}{*}{ TB543 } & $\mathrm{m}$ & 64 & larynx & pT3pN0cM0 \\
\hline & & & oropharynx & pT2pNOcM0 \\
\hline TB544 & $\mathrm{m}$ & 77 & (relapse) & cT4cN2bcM1 \\
\hline TB545 & $\mathrm{m}$ & 41 & (relapse) & pT4apN2bcM0 \\
\hline TB546 & $\mathrm{m}$ & 44 & CUP & TxN2bM0 \\
\hline TB782 & $\mathrm{m}$ & 61 & oropharynx & pT4apN2ccM1 \\
\hline
\end{tabular}

B, Fourteen postsurgery patients with no evidence of disease having received curative therapies; accessory specification of the post-surgery time frame

\begin{tabular}{|c|c|c|c|c|c|}
\hline Sample no. & Sex & Age & Tumor side & TNM-stage & Post-surgery since \\
\hline TB525 & $\mathrm{m}$ & 46 & oral cavity & pT1cN0pMx & 3.0 years \\
\hline TB526 & $\mathrm{m}$ & 67 & hypopharynx & pT3pN3cM0 & 4.0 years \\
\hline TB528 & $\mathrm{m}$ & 57 & hypopharynx & pT4pN2bcM0 & 5.0 years \\
\hline TB529 & $\mathrm{m}$ & 49 & oral cavity & pT1pN0cM0 & 18.0 days \\
\hline TB531 & $\mathrm{m}$ & 55 & nasal cavity & pT1cN0cM0 & 36.0 days \\
\hline TB532 & $\mathrm{f}$ & 78 & Gl. parotis & pT3pN0cM0 & 10.0 days \\
\hline TB768 & $\mathrm{m}$ & 61 & larynx & pT1cN0cM0 & 1.5 years \\
\hline TB777 & $\mathrm{m}$ & 65 & larynx/hypopharynx & $\mathrm{cT} 3 \mathrm{cN} 2 \mathrm{bcM} 0$ & 3.0 years \\
\hline TB778 & $\mathrm{m}$ & 44 & larynx & pT2cN0cM0 & 7.0 months \\
\hline TB779 & $\mathrm{m}$ & 53 & larynx/hypopharynx & pT4apN1M0 & 10.0 months \\
\hline TB780 & $\mathrm{m}$ & 67 & larynx & $\mathrm{pT} 2 \mathrm{pN} 1 \mathrm{cM} 0$ & 3.0 years \\
\hline TB781 & $\mathrm{m}$ & 57 & oropharynx & pT1pN2acM0 & 1.0 year \\
\hline TB783 & $\mathrm{m}$ & 69 & $\begin{array}{c}\text { hypopharynx } \\
\text { oral cavity }\end{array}$ & $\begin{array}{l}\text { pT2pN0cM0 } \\
\text { pT1pN0cM0 }\end{array}$ & 2.0 years \\
\hline TB784 & $\mathrm{m}$ & 74 & larynx & pT4pNOcM0 & 9.0 years \\
\hline
\end{tabular}

characterized by low levels of CD127, which together with a high expression of CD25 (CD25 high) helps distinguish Tregs from activated $\mathrm{CD} 4^{+} \mathrm{T}-$-lymphocytes.

Our investigations demonstrate a strong and permanent increased ratio of circulating $\mathrm{CD} 4{ }^{+} \mathrm{CD} 25^{\text {high }} \mathrm{CD} 127^{\text {low }}$ Tregs within the entire population of $\mathrm{CD}^{+} \mathrm{T}$-lymphocytes through HNSCC, which was found even in patients with no active disease after several years.

\section{Materials and methods}

Preparation of peripheral blood samples. After written informed consent, peripheral blood samples were taken from healthy blood donors and patients with HNSCC. All HNSCC tumor patients had histologically proven HNSCC, either at the time of blood draw or before (summarized in Table I). At the time of blood withdrawal, 16 patients had active disease (AD; presurgery) and 16 patients showed no evidence of disease anymore (NED; post-surgery).

As healthy controls, human Peripheral blood mononuculear cells (PBMCs) were isolated from buffy coats provided by the blood bank of the University of Lübeck, Germany. Blood donors were 18-65-year-old healthy men and women who were tested negative for HIV and hepatitis B and C viruses. Serum, used for the CCL22-ELISA, was taken from 21 voluntary donors. Patient characteristics and disease classification are 
summarized in Table I. PBMCs were prepared from buffy coats by Ficoll-Hypaque density gradient centrifugation and subbjected to flow cytometric analyses.

Cell culture. Permanent HNSCC cell lines BHY (DSMZ Germany) (38), PCI-1 and PCI-13 (generously provided by T.L. Whiteside, Pittsburgh Cancer Institute) were cultured in DMEM-medium (Dulbecco's Modified Eagle Medium, Gibco) supplemented with $10 \%$ FCS, $1 \mathrm{mM}$ glutamine and $0.1 \mathrm{mM}$ sodium pyruvate and incubated in cell culture flasks with $37^{\circ} \mathrm{C}$ and $5 \% \mathrm{CO}_{2}$ in an incubator.

Flow cytometry. Surface antigen staining was performed as described previously (39). Cells were stained with peridinin chlorophyll (CD4-PerCP, BD Biosciences), allophycocyanin (CD25-APC, eBioscience), fluorescein-5-isothiocyanate (CD25-FITC, eBioscience), phycoerythrin-Cy7 (CD45RAPE-CY7, BD Biosciences), GITR-FITC (eBioscience), CD152, phycoerythrin (CTLA-4-PE, BD Biosciences), phycoerythrin (CD122-Pe, BD Biosciences), phycoerythrinCy7 (CCR7-PE-CY7, BD Biosciences), phycoerythrin-Cy7 (CCR4-PE-CY7, BD Biosciences), fluorescein-5-isothiocyanate (CD62L-FITC, BD Biosciences) antibodies as specified in figure legends. For intracellular staining of FOXP3 and CTLA-4 (CD152), PE anti-human FOXP3 Flow Kit from BioLegend was used. For measuring of intracellular CCL22, cells were permeabilized using saponin buffer (PBS, 0.1 saponin, $1 \%$ FCS and $1 \mathrm{M}$ HEPES), stained with monoclonal anti-human CCL22/MDC antibody (R\&D Systems) and the corresponding secondary antibody PE goat anti-mouse Ig (BD Biosciences) or APC goat anti-mouse Ig (BD Biosciences). Propidiumiodide was used to determine dead cells. Isotype control monoclonal antibodies were used to estimate the non-specific binding of target primary antibodies to antigens. Samples were analyzed on a FACSCanto (BD Biosciences, Heidelberg, Germany) and data acquisition was performed using the FACSDiva software (BD Biosciences).

Cytokine analysis. The Enzyme-linked immunosorbet assay (ELISA) was used for determination of CCL22/MDC levels in supernatants according to the manufacturer's instructions (Quantikine Human MDC, R\&D Systems). This cytokine assay allows the multiplexed quantitative measurement of multiple cytokines in a single small volume of cell culture supernatant or serum. The minimum detectable dose of MDC is typically $<62.5 \mathrm{pg} / \mathrm{ml}$. The cytokine array was analyzed by a specialized microplate reader (Microplate Manager 5.2, Bio-Rad) set to $450 \mathrm{~nm}$ and revealed data were calculated using the Microplate spectrophotometer (Microplate Manager software, Bio-Rad). Data were expressed as the means \pm SD. Serum, used for the CCL22-ELISA, was taken from 21 single voluntary donors and 19 tumor patients.

Protein analysis. CCL22 protein expression was analyzed in the lysate of PCI-1, PCI-13, BHY (see above), adenoid vegetations (H437), human tongue squamous cell carcinoma (Cal27) and HaCaT. HaCaT is a permanent epithelial (immortalized keratinocyte cell line) cell line from adult human skin and serves as a positive control for CCL22 production (40). The adenoid vegetations (H437) were used as a negative control. Cell extracts were prepared and solubilized and protein concentrations were determined using the Bio-Rad protein assay kit (Bio-Rad GmbH, Munich, Germany) with bovine serum albumin (BSA) as a standard. Aliquots of protein extracts $(60 \mu \mathrm{g})$ were run on SDS-PAGE and were then transferred onto a nitrocellulose membrane. Blots were decorated with monoclonal anti-human CCL22/MDC antibody (R\&D Systems) and mouse anti- $\beta$-actin antibody as loading control (mAbcam).

Statistical analysis. Statistical analysis was performed using the SPSS 12.0 program (SPSS Inc., Chicago, USA), SigmaPlot 10.0 (Systat Software Inc) and Office 2003 (Microsoft Corporation, Redmont, USA). Data are expressed as mean \pm SD resulting from at least four independent experiments. The achieved results were tested by means of KolmogorovSmirnov-test regarding normal distribution. The significance of the results was determined using the Student t-test for independent samples (highly significant, $\mathrm{p}<0.01$; significant, $0.01 \leq \mathrm{p} \leq 0.05$; trend, $0.05<\mathrm{p}<0.1$ ); otherwise statistical analysis was performed using the Mann-Whitney-U-test.

\section{Results}

Increased ratio of Tregs within $\mathrm{CD}^{+} \mathrm{T}$ cells in HNSCC patients. The abundance of circulating lympocytes, $\mathrm{CD}^{+}{ }_{-}$, $\mathrm{CD} 4{ }^{+} \mathrm{CD} 25^{+-}, \mathrm{CD} 4{ }^{+} \mathrm{CD} 25^{\text {high }} \mathrm{CD} 127^{\text {low }}$ - and $\mathrm{CD} 4{ }^{+} \mathrm{CD} 25^{\text {low }}$ CD127 $7^{\text {high }}$ T cells in the peripheral blood of patients with HNSCC was analyzed using flow cytometry. The presented study included 25 patients with HNSCC and 27 healthy controls, which are summarized in Table I.

Patients with HNSCC showed a highly significant increase of $\mathrm{CD} 4{ }^{+} \mathrm{CD} 25^{\text {high }} \mathrm{CD} 127^{\text {low }}$ Tregs among CD4 ${ }^{+} \mathrm{T}$-lymphocytes in comparison with healthy controls $(3.4 \pm 2.5 \%$ in HNSCC vs. $1.8 \pm 1.7 \%$ in $\mathrm{NC} ; \mathrm{p}<0.01$ ) (Fig. $1 \mathrm{~A}$ and $\mathrm{B}$ ). Human $\mathrm{CD} 4^{+} \mathrm{CD} 25^{+}$cells are subdivided in suppressor $\mathrm{CD} 4^{+} \mathrm{CD} 25^{\text {high }}$ and $\mathrm{CD} 4{ }^{+} \mathrm{CD} 25^{\text {low }} \mathrm{T}$ cells, which are non-suppressive, antigen-experienced activated $\mathrm{CD}^{+}{ }^{+} \mathrm{T}$ cells (36). A low expression of CD127 (CD127low) together with a high expression of CD25 (CD25 $\left.{ }^{\text {high }}\right)$ is supposed to be specific for suppressive Treg cells (37). Our data show that up to $98 \%$ of $\mathrm{CD} 4{ }^{+} \mathrm{CD} 25^{+} \mathrm{T}$ cells are non-suppressive $\mathrm{CD} 4{ }^{+} \mathrm{CD} 25^{\text {low }} \mathrm{T}$ cells and normal controls displayed significantly higher percentages of $\mathrm{CD} 4{ }^{+} \mathrm{CD} 25^{\text {low }} \mathrm{CD} 127^{\text {high }} \mathrm{T}$ cells relative to $\mathrm{HNSCC}$ patients $(98.2 \pm 1.7 \%$ in NC vs. $96.6 \pm 2.5 \%$ in HNSCC; $p<0.01)$. In the TNM-stages, no significant correlation between tumor stage and the level of circulating Treg cells was observed in the peripheral blood of HNSCC tumor patients.

Phenotypic analysis of $\mathrm{CD}^{+} \mathrm{T}$ cell subsets. Circulating $\mathrm{CD} 4{ }^{+} \mathrm{CD} 25^{\text {high }} \mathrm{CD} 127^{\text {low }}$ lymphocytes from HNSCC patients and healthy controls were analyzed concerning the expression of functional proteins forkhead box P3 (FoxP3), membrane glucocorticoid-induced tumor-necrosis factor receptor familyrelated gene (GITR), immunregulatory protein cytolytic Tlymphocyte-associated antigen 4 protein or CD152 (CTLA-4), chemokine receptors CCR7 and CCR4, the 'homing receptor' CD62L, CD45RA and the ß-chain of the IL-2-receptor CD122. In patients with $\mathrm{HNSCC} 48.3 \%$ of the analyzed CD4+CD25 high CD127 $7^{\text {low }}$ Treg cells expressed the transcriptional activator 


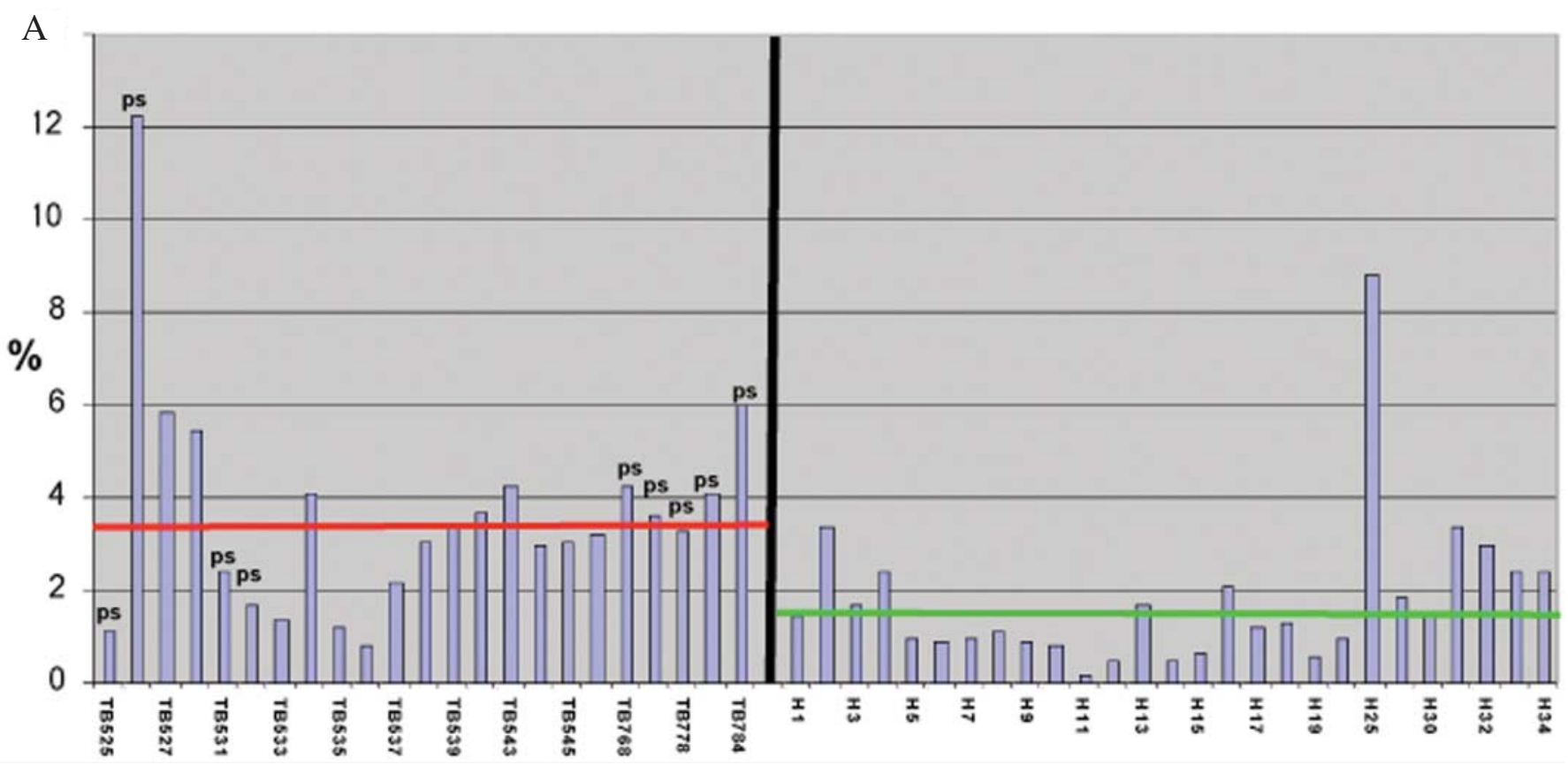

B

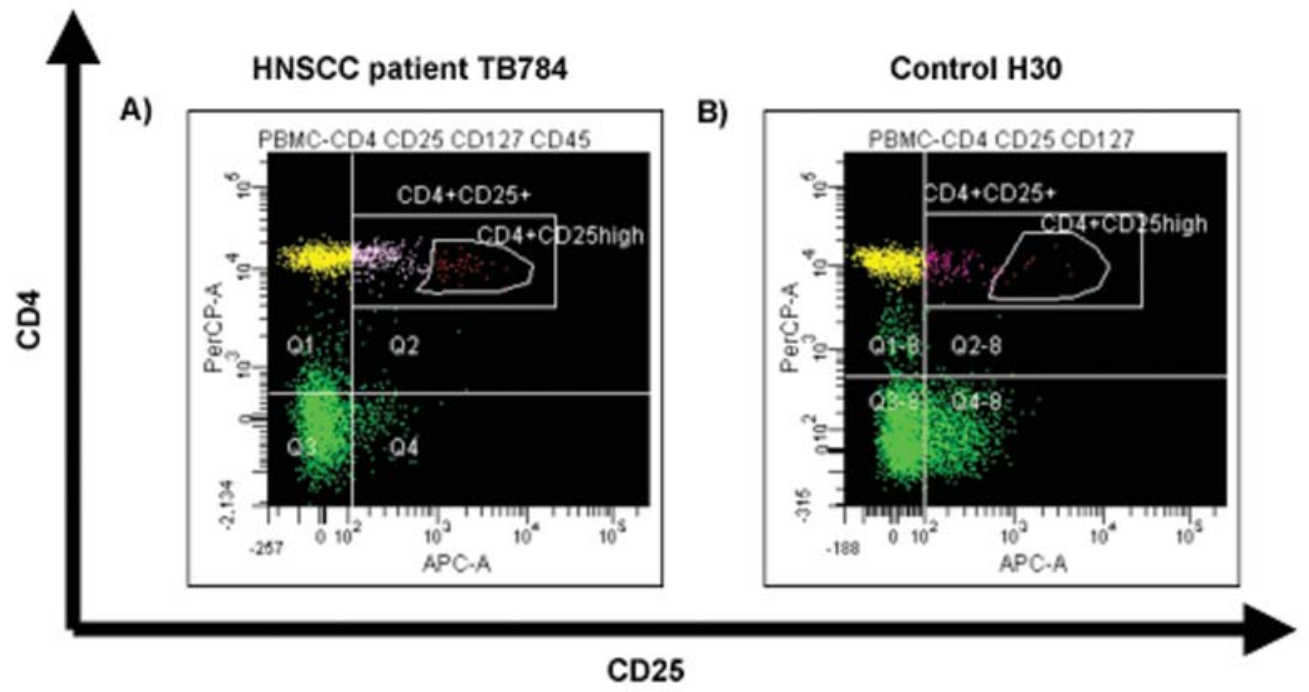

Figure 1. Increase of CD4 ${ }^{+} \mathrm{CD} 25^{\text {high }}$ Treg cells in peripheral blood of $\mathrm{HNSCC}$ patients compared with healthy controls. The abundance of circulating CD4 ${ }^{+} \mathrm{CD} 25^{\text {high }}$ Treg cells in PBMC of 25 HNSCC tumor patients (TB) and 27 healthy controls (H) was analyzed by flow cytometry and compared to the overall level (\%) of CD4 ${ }^{+}$ T-lymphocytes. (A) Red line, average of $\mathrm{CD} 4^{+} \mathrm{CD} 25^{\text {high }}$ Treg within $\mathrm{CD} 4^{+} \mathrm{T}$ cells in patients with $\mathrm{HNSCC}$; green line, average of CD4 $4^{+} \mathrm{CD} 25^{\text {high }} \mathrm{Treg}$ within $\mathrm{CD} 4^{+}$ T cells in normal controls. Fourteen HNSCC tumor patients are patients with an active disease; 11 patients marked with 'ps' are patients showing no evidence of disease (post-surgery) and oncological treatment of the tumor was carried out between 10 days and 9 years ago. Our data demonstrate strongly increased ratios of $\mathrm{CD} 4{ }^{+} \mathrm{CD} 25^{\text {high }}$ Treg cells to $\mathrm{CD} 4^{+} \mathrm{T}$ lymphocytes in the peripheral blood of patients with HNSCC compared to healthy donors with individually deviating levels. These findings are independent of activity of disease. Patients with HNSCC, TB525-TB539, TB541, TB543-TB546, TB768, TB777-TB779, TB784; normal controls: H1-H20, H25, H28, H30-H34. (B) Example of enrichment in CD4 ${ }^{+} \mathrm{CD} 25^{+}, \mathrm{CD} 4{ }^{+} \mathrm{CD} 25^{\text {high }}$ and $\mathrm{CD} 4{ }^{+} \mathrm{CD} 25^{\text {low }}$ Treg cells in PBMCs of a single patient with HNSCC (TB784) in comparison with a healthy control (H30). The PBMCs of the HNSCC patient were found to contain $28.6 \%$ CD4+CD25+ Treg cells, that consist of $6 \% \mathrm{CD} 4^{+} \mathrm{CD} 25^{\text {high }}$ and $94 \% \mathrm{CD} 4^{+} \mathrm{CD} 25^{\text {low }}$ Treg cells relative to $12 \% \mathrm{CD} 4^{+} \mathrm{CD} 25^{+}$Treg cells, $1.5 \% \mathrm{CD} 4{ }^{+} \mathrm{CD} 25^{\text {high }}$ and $98.5 \% \mathrm{CD} 4{ }^{+} \mathrm{CD} 25^{\text {low }}$ Treg cells in the normal control.

protein FoxP3, 22.7\% expressed GITR, 68.6\% CTLA-4, 54.8\% expressed CCR7, 86.9\% CCR4, 78.5\% CD62L, $51.4 \%$ CD45RA and $34.96 \%$ expressed CD122. Comparing the percentages of the different markers on $\mathrm{CD} 4{ }^{+} \mathrm{CD} 25^{\text {high }} \mathrm{CD} 127^{\text {low }}$ Treg cells in HNSCC patients with healthy controls, there existed no significant difference in the expression of GITR, CTLA-4, CD45RA, CCR4 and CD62L. However, CCR7 showed a tendency $(0.05<\mathrm{p}>0.1)$ for a higher expression of $\mathrm{CD} 4{ }^{+} \mathrm{CD} 25^{\text {high }} \mathrm{CD} 127^{\text {low }}$ Treg cells in HNSCC patients.
On the other hand, the amount of CD122 (interleukin-2, IL-2/IL-15 receptor 3 -chain), which plays a role in regulating normal lymphocyte development in vivo, expressing $\mathrm{CD}^{+}$ CD25 ${ }^{\text {high }} \mathrm{CD} 127^{\text {low }}$ Treg cells were highly significantly increased in healthy controls relative to HNSCC patients (60.8 vs. $35 \%$; $\mathrm{p}<0.01)$. Consistent with the significant increase of $\mathrm{CD} 4{ }^{+} \mathrm{CD} 25^{\text {high }} \mathrm{CD} 127^{\text {low }}$ Treg cells in the peripheral blood of patients with HNSCC relative to healthy controls, our data displayed that the amount in percentage of Foxp3 (48.3 vs. 
A

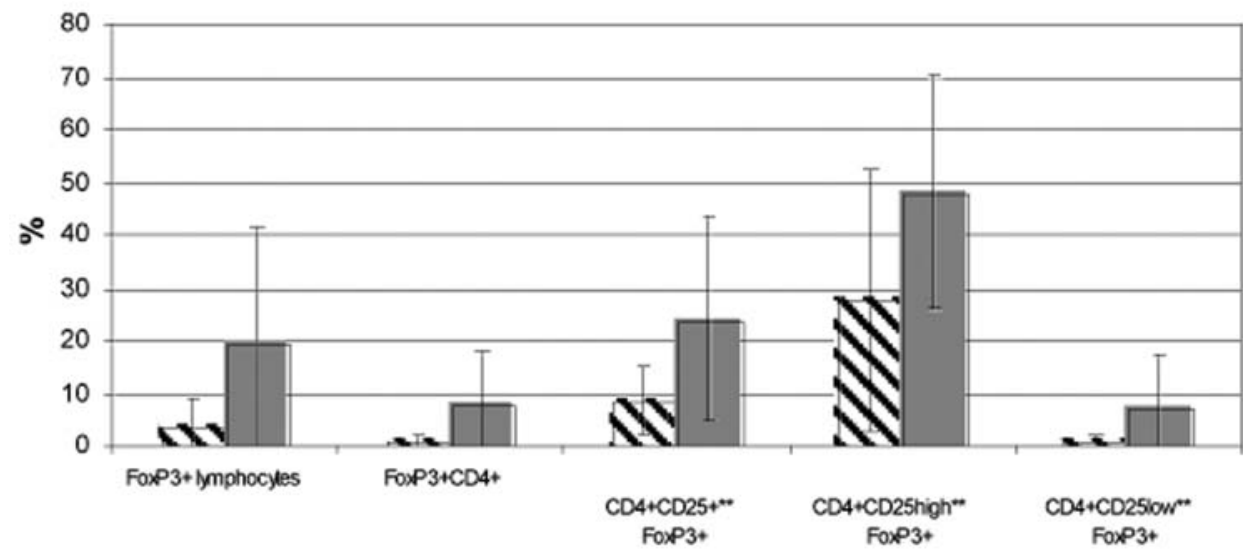

B

\begin{tabular}{|c|c|c|c|}
\hline Foxp3 on different cells & Average HNSCC in & Average $\mathrm{NC}$ in & p-value \\
\hline FoxP3' fymphocytes & $20,1^{n}$ & 3,9 & $p<0,01$ \\
\hline CD4' FoxP3' & 8 & 1,4 & $0,01>p<0,05$ \\
\hline $\operatorname{CD} 4^{*} \mathrm{CD} 25^{\circ}$ & 24,3 & 9 & $p<0,01$ \\
\hline CD4* CD25high** & 48,3 & 27,8 & $p<0,01$ \\
\hline $\mathrm{CD} 4^{\circ}$ CD25low ${ }^{* *}$ FoxP $3^{\circ}$ & 7,2 & 1,2 & $0,01>p<0,05$ \\
\hline
\end{tabular}

Figure 2. Expression of Foxp3 expressed as average of percentage with SD in patients with HNSCC (red bar) relative to normal controls (green bar). We analyzed a possible expression of Foxp 3 on lymphocytes in general, on $\mathrm{CD} 4^{+}, \mathrm{CD} 4^{+} \mathrm{CD} 25^{+} \mathrm{T}$ cells, CD $4^{+} \mathrm{CD} 25^{\text {high }} \mathrm{CD} 127^{\text {low }} \mathrm{Treg}$ cells $($ red box) and on $\mathrm{CD} 4{ }^{+} \mathrm{CD} 25^{\text {low }} \mathrm{CD} 127^{\text {high }} \mathrm{T}$ cells. (A) The analyzed cells in PBMCs in HNSCC patients as well as in the normal controls displayed an expression of Foxp3, however the Foxp3 expression is significantly higher in cells in patients with HNSCC. (B) Listing of the frequencies and p-values of cells expressing Foxp3 in patients relative to normal controls.

27.8\%; $\mathrm{p}<0.01$ ) expressing $\mathrm{CD} 4^{+} \mathrm{CD} 25^{\text {high }} \mathrm{CD} 127^{\text {low }}$ Treg cells were also highly significantly increased in these patients (Fig. 2). The transcription factor Foxp3 has been shown to be critical for the development and function of $\mathrm{CD} 4{ }^{+} \mathrm{CD} 25^{\text {high }}$ regulatory T cells. However, recently FOXP3 expression has been shown to be induced upon activation of human $\mathrm{CD}^{+}$ $\mathrm{T}$ cells (41) and the expression is not suppossed to be restricted to Treg cells. Hence we analyzed a possible expression of Foxp3 in lymphocytes, $\mathrm{CD} 4^{+}, \mathrm{CD} 4{ }^{+} \mathrm{CD} 25^{+}$and $\mathrm{CD} 4{ }^{+} \mathrm{CD} 25^{\text {low }}$ CD127 ${ }^{\text {high }} \mathrm{T}$ cells (Fig. 2). We showed that all analyzed cells displayed an expression of Foxp3. However, the percentage of Foxp3 expression was again significantly higher in patients with HNSCC (Fig. 2B).

HNSCC induces a permanent shift of Treg abundance. Analyzed patients with HNSCC were subdivided into patients with an active tumor disease (AD) $(n=14)$ and postsurgery patients $(n=11)$ with no evidence of an active disease (NED) after an oncologic therapy. Oncological treatment (surgery \pm radiochemotherapy) of the tumor was carried out between 10 days and 9 years ago.

Surprisingly, the mean ratio of $\mathrm{CD} 4{ }^{+} \mathrm{CD} 25^{\text {high }}$ Foxp $3^{+}$Treg cells to the total of peripheral blood $\mathrm{CD}^{+} \mathrm{T}$ cells was still significantly increased in all analyzed samples, even up to 9 years after active disease and oncologic therapy (Fig. 1A). Our data demonstrate that HNSCC leads to a permanent shift of the Treg abundance with hardly recognizable recovery rates.

Even though we found no difference in the mean ratio of $\mathrm{CD} 4{ }^{+} \mathrm{CD} 25^{\text {high }} \mathrm{CD} 127^{\text {low }}$ Treg cells between patients with AD and NED, we noted that the percentage of GITR and CCR4 expressing Treg cells were significantly higher among PBMCs from HNSCC patients with an active stage of disease (AD). In addition the expression levels of CCR 4 and GITR were significantly higher on the surface of single $\mathrm{CD} 4{ }^{+} \mathrm{CD} 25^{\text {high }}$ CD127 $7^{\text {low }}$ Treg cells in patients with active disease, declared by the mean fluorescence intensity measured by flow cytometry. Moreover, our data displayed, that patients before being treated with an oncological therapy show significantly higher percentages of GITR and Foxp3 expressing lymphocytes, CD $4^{+}$ and $\mathrm{CD} 4{ }^{+} \mathrm{CD} 25^{\text {low }} \mathrm{T}$ cells.

CCL22 as a chemoattractant in HNSCC. The ability of HNSCC to autonomously produce CCL22 was investigated using permanent HNSCC cell lines PCI-1 and PCI-13. Flow cytometric analyses demonstrate a significant production of CCL22 (Fig. 3). Furthermore, our data displayed an extracellular expression of CCL22 on the surface of the analyzed HNSCC cell lines, which is highly significantly lower $(\mathrm{p}<0.01)$ than the detected intracellular expression (Fig. 3A).

In addition, the CCL22 expression was analyzed in protein lysates of permanent HNSCC cell lines PCI-1, BHY, adenoid vegetations (H437) (Fig. 3B), as well as PCI-13, Cal 27 and HaCaT by Western blotting (Fig. 3B). Fig. 3B demonstrates that CCL22 can be detected in all analyzed permanent cell lines with similar expression levels. The adenoid vegetations (H437) served as a negative control and showed no production of CCL22. The human keratinocyte cell line HaCaT was used as a positive control as described in previous studies $(40,42)$.

To evaluate the relationship between the level of CCL22 and the frequencies of regulatory $\mathrm{CD} 4{ }^{+} \mathrm{CD} 25^{\text {high }} \mathrm{T}$ cells in 
A
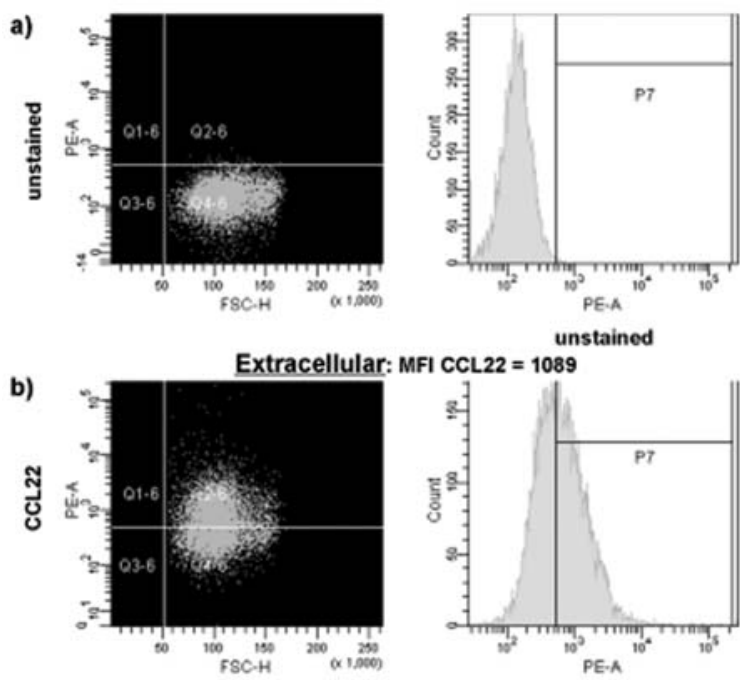

unstained

b)
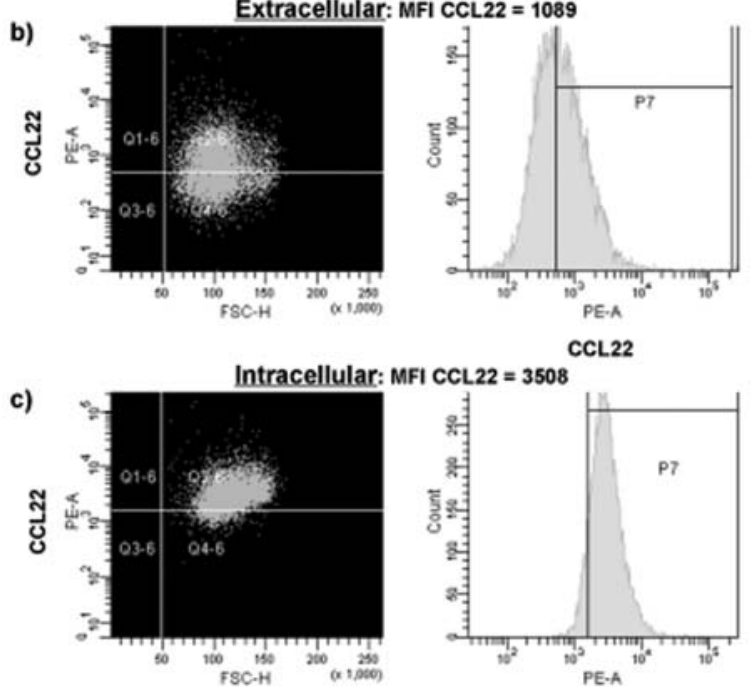

CCL22

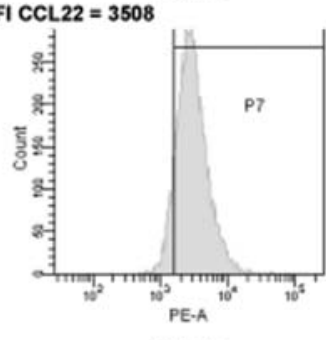

CCL.22

B

a)

B-Actin

CCL22

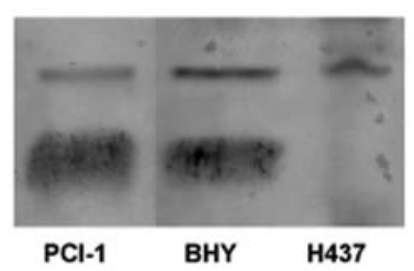

b)

B-Actin

CCL22

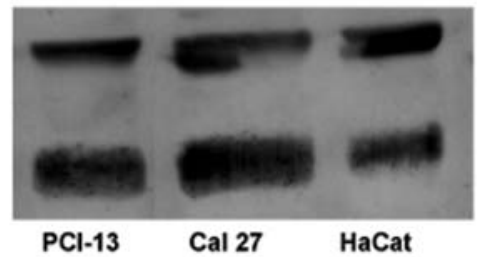

Figure 3. Expression of the chemokine CCL22 by Treg cells and HNSCC cell lines. (A) a-c, Extracellular and intracellular expression of CCL22 on the analyzed HNSCC cell line PCI-1. Permanent HNSCC cell lines PCI-1 and PCI-13 were stained with or without Fix/Perm buffer set for intracellular or extracellular staining respectively and stained with CCL22-antibody inclusive secondary antibody and flow cytometric analysis indicated the production of CCL22 (c). Furthermore our data displayed an extracellular expression of CCL22 on the surface of the analyzed HNSCC cell lines, which is highly significantly lower $(\mathrm{p}<0.01)(\mathrm{b})$ than the detected intracellular expression (c). (B) Analysis of the CCL22 protein expression in the lysate of the HNSCC-cell lines PCI-1, BHY, PCI-13 and Cal-27, adenoid vegetations (H437) and the human keratinocyte cell line HaCaT by Western blotting with CCL22-antibody and B-actin and corresponding secondary antibody. B-actin served as a loading control. a, Western blot with the lysate of PCI-1, BHY, adenoid vegetations (H437). CCL22 was detected in PCI-1 and BHY cell lines. The adenoid vegetations (H437) served as a negative control and showed no production of CCL22. b, Cal-27 showed a similar amount of CCL22 relative to PCI-13. The production of CCL22 by the human keratinocyte cell line HaCaT is well known in previous studies, hence we used HaCat as a positive control for CCL22 production in HNSCC cell lines.

HNSCC patients, we examined the expression of chemokine CCL22/MDC in the serum of 19 tumor patients and 21 healthy blood donors, which are summarized in Table I.

Our data demontrate, that there are no significant differences of the CCL22 levels in the peripheral blood of tumor patients compared to healthy donors, but only individual deviations. Furthermore, our data show no correlation between HNSCC tumor stage (TNM) and the level of CCL22 in the peripheral blood (Fig. 4).

Since IFN- $\gamma$ is known to suppress constitutive expression of CCL22 in mature macrophages and dendritic cells (43), we analyzed its influence on the CCL22 production in HNSCC. Therefore, permanent HNSCC cell lines were cultivated in $5 \mathrm{ml}$ DMEM-medium with $2 \mu \mathrm{l}(4,000 \mathrm{pg} / \mathrm{ml})$ recombinant human IFN- $\gamma$ for 12,48 or $72 \mathrm{~h}$, respectively. Cells were analyzed by flow cytometry and the level of CCL22 before and after incubation with INF- $\gamma$ was declared in Mean Fluorescence Intensity (MFI), which is an admeasurement for adhesion of antibodies and for the expression and production of CCL22. The decrease in the CCL22 level after incubation with INF- $\gamma$ was specified in percent (Fig. 5). Our data indicate that INF- $\gamma$ leads to a reduced expression of CCL22 in HNSCC.

\section{Discussion}

In recent years, a variety of immunoregulatory functions and different subsets of Tregs in cancer patients have been described and the concept has emerged that peripheral tolerance to tumors is maintained and enhanced by Tregs $(14,19,22,44)$. In this work we demonstrate that malignant head and neck 


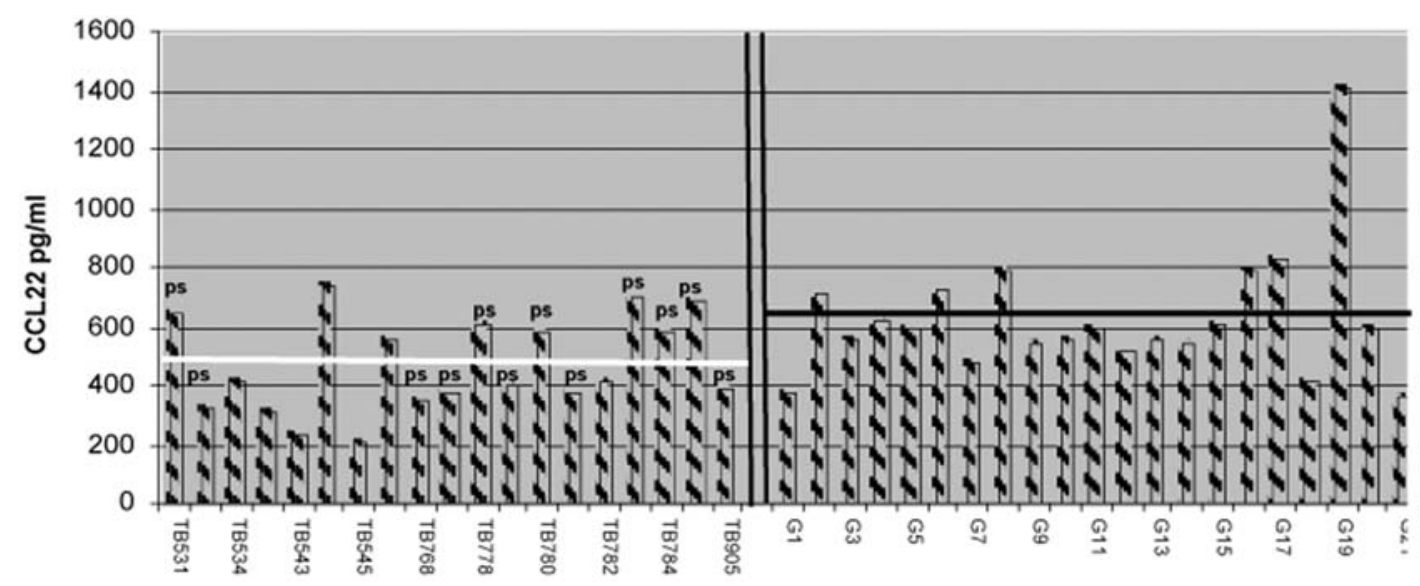

Figure 4. Level (pg/ml) of the chemokine CCL22/MDC in the serum of 19 tumor patients (TB) relative to 21 healthy controls (H). 7 HNSCC tumor patients are patients with an active disease; 12 patients marked with 'ps' are patients showing no evidence of disease (post-surgery) and oncological treatment of the tumor was carried out between 10 days and 9 years ago. The level of CCL22 was measured by Enzyme-linked Immunosorbet Assay (ELISA). The average levels of CCL22 in tumor patients and healthy controls are illustrated by a white and black horizontal line, respectively. The level of CCL22 in the blood samples of tumor patients, active disease or no evidence of disease, does not differ from the level measured in the serum of healthy controls. The CCL22 level did not show any correlation with the TNM-Stage or the number of Treg cells.

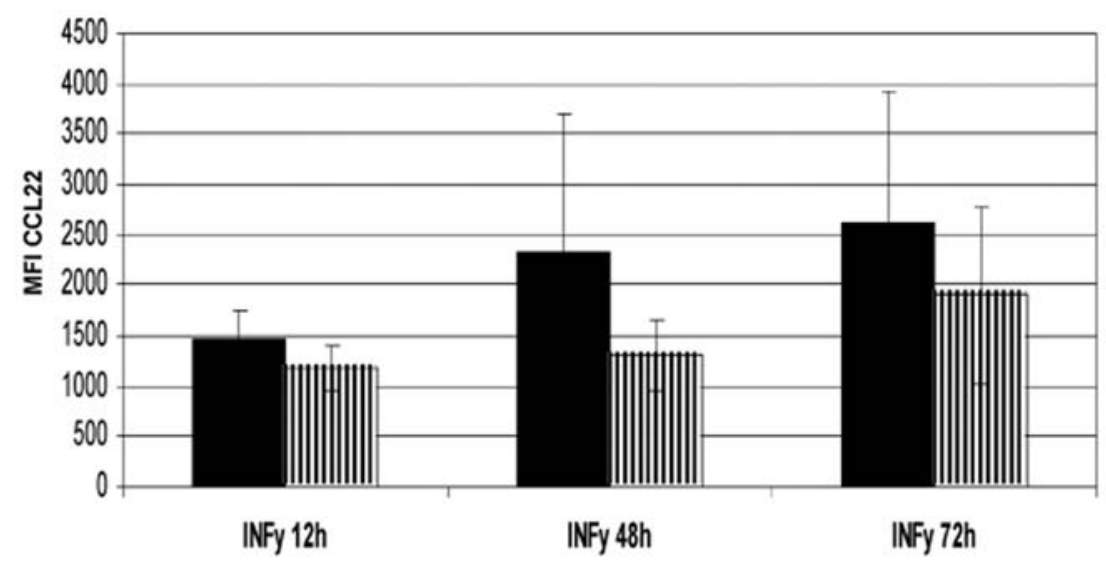

Figure 5. Downregulation of the CCL22 production and CCR4 expression through IFN- $\gamma$. The level of CCL22 expression is declared in mean fluorescence intensity (MFI) together with the respective standard deviations. Our data indicate that INF- $\gamma$ leads to a reduced expression of CCL22 in HNSCC (Blue bar, mean fluorescence intensity of CCL22 without any incubation with INF- $\gamma$; Purple bar, mean fluorescence intensity of CCL22 after incubation with INF- $\gamma$ ).

cancer strongly modulates the abundance of $\mathrm{CD} 4{ }^{+} \mathrm{CD} 25^{\text {high }}$ regulatory $\mathrm{T}$ cells in the peripheral blood of HNSCC tumor patients for a long time period.

We show that circulating $\mathrm{CD} 4+\mathrm{CD} 25^{\text {high }}$ Tregs in HNSCC patients possess a characteristic phenotype determining their regulatory function such as $\mathrm{CD} 25^{+}$, transcriptional activator Foxp $3^{+}$, CTLA-4 ${ }^{+}$(cytotoxic T-lymphocyte-associated antigen 4; CD152), glucocorticoid-induced tumor necrosis

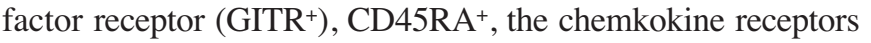
$\mathrm{CCR}^{+}$and $\mathrm{CCR}^{+}$and the 'homing' receptor $\mathrm{CD}^{+} 2 \mathrm{~L}^{+}$. Significantly increased levels not only of CD4 ${ }^{+} \mathrm{CD} 25^{\text {high }} \mathrm{Foxp}^{+}$ Treg cells, but also of Foxp3 expressing lymphocytes, CD $4^{+}$ T lymphocytes, $\mathrm{CD} 4{ }^{+} \mathrm{CD} 25^{+}$and $\mathrm{CD} 4{ }^{+} \mathrm{CD} 25^{\text {low }} \mathrm{CD} 127^{\text {high }}$ $\mathrm{T}$ cells were found in patients with HNSCC compared to healthy controls. In different solid tumors, the accumulation of Foxp $3^{+}$Tregs has been associated with reduced survival rates of tumor patients $(34,45-47)$. Hence the greater number of Foxp3 expressing Treg cells may reflect the increased suppressive activity seen in patients with HNSCC (33). However, it is important to mention that according to Hori et al (48) the expression of Foxp3 on T-lymphocytes does not necessarily implicate suppressive abilities.

Our data demonstrate the long-term character of tumor modulated Treg abundance and the CCL22-level in patients with HNSCC. These data are in accordance with other recent studies, which implicate that malignant tumors, independently from the disease stage, site or nodal involvement, have a strong impact on the homeostasis of lymphocytes long after the tumor is removed, even in the absence of any chemo- or radiotherapeutic treatments $(9,49)$. Even though we found no difference in the mean ratio of $\mathrm{CD} 4{ }^{+} \mathrm{CD} 25^{\text {high }} \mathrm{CD} 127^{\text {low }}$ Treg cells between patients with $\mathrm{AD}$ and NED, we noted however that levels of GITR and CCR4 expressing Treg cells were significantly higher among PBMCs from HNSCC patients with an active stage of disease (AD). GITR as well as CCR4 can be upregulated on T cells upon activation and TCR and CD28 engagement (50). The increased expression of the receptor on single Treg cells in patients with an active disease 
might be consistent with a higher response of Treg cells to the chemoattractant CCL22. Furthermore, the fact that patients with active disease show a significant increase of GITR expressing Treg cells is of special interest, because GITR is a typical Treg surface marker, that is supposed to abrogate Treg cell mediated suppression upon stimulation of GITR (51). But according to a previous (52) while GITR triggering weakens suppressor activity, it can induce Treg proliferation and expansion $(53,54)$. Furthermore, after GITR costimulation, Treg cells are supposed to regain their suppressive activity. This fact can imply, that the final outcome of a transient inhibition by GITR of suppressive activity and an increase of Treg proliferation could result in an overall increase of suppressor activity (52).

CCL22 binds to and activates the G-protein-coupled CCR4, a CC chemokine receptor, that is primarily expressed by $\mathrm{CD} 4^{+}$ and $\mathrm{CD}^{+}$lymphocytes with a Th2 phenotype and $\mathrm{CD} 25^{+}$ regulatory $\mathrm{T}$ cells (55-59), but also by natural killer cells, dendritic cells and macrophages (60). CCR4 is supposed to be important for regulating immune balance (61). Curiel et al (34) have shown, that tumor cells and microenvitonmental macrophages in ovarian carcinoma produce CCL22, which mediates migration of regulatory $\mathrm{T}$ cells to the tumor. We showed in our study, that HNSCC is also able to autonomously produce CCL22.

Our data demonstrate that IFN- $\gamma$ is able to downregulate CCL22 production in HNSCC. Interferon- $\gamma$ is a representative of Th1 cytokines (62) and it is secreted by Th1 cells, dendritic cells and natural killer cells. INF- $\gamma$ has antiviral, immunoregulatory and anti-tumor properties. Immune responses in HNSCC tumor patients have been shown to be biased toward the secretion of Th2 cyokines, which prevent effective antitumor Th1 immune responses and so facilitate the production of CCL22 and in succession the recruitment of Tregs to tumor sites $(63,64)$.

In conclusion, the increase of regulatory T cells in HNSCC tumor patients might stand for a reduced anti-tumor immunity and therefore contribute to an optimized tumor immune evasion and progression or recurrence of head and neck cancer.

\section{Acknowledgements}

We are grateful to Ewelina Szymanski and Brigitte Wollmann for skillful support in several parts of this work and all members of the Department of Otorhinolaryngology for helpful discussions and a comfortable atmosphere. Furthermore, we thank T.L. Whiteside (Pittsburgh Cancer Institute) for providing the permanent HNSCC cell lines used in this work. This work was supported by grants of the following funding bodies, Mildred-Scheel-Stiftung (Deutsche Krebshilfe), the Monika-Kutzner-Stiftung, the Werner-and-Klara-Kreitz-Stiftung and the Rudolf-Bartling-Stiftung.

\section{References}

1. Luce D, Guenel P, Leclerc A, Brugere J, Point D and Rodriguez J: Alcohol and tobacco consumption in cancer of the mouth, pharynx, and larynx: a study of 316 female patients. Laryngoscope 98: 313-316, 1988.

2. Snow GB: Follow-up in patients treated for head and neck cancer: how frequent, how thorough and for how long? Eur J Cancer 28: 315-316, 1992
3. Berrino F, Esteve $\mathrm{J}$ and Coleman MP: Basic issues in estimating and comparing the survival of cancer patients. IARC Sci Publ, pp1-14, 1995.

4. St John MA, Abemayor E and Wong DT: Recent new approaches to the treatment of head and neck cancer. Anticancer Drugs 17: 365-375, 2006.

5. Kraunz KS, McClean MD, Nelson HH, Peters E, Calderon $\mathrm{H}$ and Kelsey KT: Duration but not intensity of alcohol and tobacco exposure predicts p16INK4A homozygous deletion in head and neck squamous cell carcinoma. Cancer Res 66: 4512-4515, 2006.

6. Chin D, Boyle GM, Porceddu S, Theile DR, Parsons PG and Coman WB: Head and neck cancer: past, present and future. Expert Rev Anticancer Ther 6: 1111-1118, 2006.

7. Bauernhofer T, Kuss I, Henderson B, Baum AS and Whiteside TL: Preferential apoptosis of CD56dim natural killer cell subset in patients with cancer. Eur J Immunol 33: 119-124, 2003.

8. Kross KW, Heimdal JH, Olsnes C, Olofsson J and Aarstad HJ: Head and neck squamous cell carcinoma spheroid- and monocyte spheroid-stimulated IL-6 and monocyte chemotactic protein-1 secretion are related to TNM stage, inflammatory state and tumor macrophage density. Acta Otolaryngol 125: 1097-1104, 2005.

9. Kuss I, Hathaway B, Ferris RL, Gooding W and Whiteside TL: Decreased absolute counts of $\mathrm{T}$ lymphocyte subsets and their relation to disease in squamous cell carcinoma of the head and neck. Clin Cancer Res 10: 3755-3762, 2004.

10. Whiteside TL: Immunobiology of head and neck cancer. Cancer Metastasis Rev 24: 95-105, 2005.

11. McHugh RS and Shevach EM: The role of suppressor T cells in regulation of immune responses. J Allergy Clin Immunol 110: 693-702, 2002.

12. Miyara $M$ and Sakaguchi S: Natural regulatory T cells: mechanisms of suppression. Trends Mol Med 13: 108-116, 2007.

13. Shimizu J, Yamazaki S and Sakaguchi S: Induction of tumor immunity by removing $\mathrm{CD} 25^{+} \mathrm{CD} 4^{+} \mathrm{T}$ cells: a common basis between tumor immunity and autoimmunity. J Immunol 163: 5211-5218, 1999 .

14. Szczepanski MJ, Szajnik M, Czystowska M, Mandapathil M, Strauss L, Welsh A, Foon KA, Whiteside TL and Boyiadzis M: Increased frequency and suppression by regulatory $\mathrm{T}$ cells in patients with acute myelogenous leukemia. Clin Cancer Res 15: 3325-3332, 2009 .

15. Strauss L, Bergmann C, Szczepanski M, Gooding W, Johnson JT and Whiteside TL: A unique subset of $\mathrm{CD} 4{ }^{+} \mathrm{CD} 25^{\text {high }} \mathrm{Foxp} 3^{+}$ $\mathrm{T}$ cells secreting interleukin-10 and transforming growth factorbeta1 mediates suppression in the tumor microenvironment. Clin Cancer Res 13: 4345-4354, 2007.

16. Whiteside TL: Immunobiology and immunotherapy of head and neck cancer. Curr Oncol Rep 3: 46-55, 2001.

17. Whiteside TL: 22. Immune responses to malignancies. J Allergy Clin Immunol 111: S677-S686, 2003.

18. Whiteside TL: Immune suppression in cancer: effects on immune cells, mechanisms and future therapeutic intervention. Semin Cancer Biol 16: 3-15, 2006.

19. Ferrone $\mathrm{S}$ and Whiteside TL: Tumor microenvironment and immune escape. Surg Oncol Clin N Am 16: 755-774, viii, 2007.

20. Zwar TD, van Driel IR and Gleeson PA: Guarding the immune system: suppression of autoimmunity by $\mathrm{CD} 4{ }^{+} \mathrm{CD} 25^{+}$immunoregulatory T cells. Immunol Cell Biol 84: 487-501, 2006.

21. Danese $\mathrm{S}$ and Rutella S: The Janus face of $\mathrm{CD} 4{ }^{+} \mathrm{CD} 25^{+}$regulatory T cells in cancer and autoimmunity. Curr Med Chem 14: 649-666, 2007.

22. Wang HY and Wang RF: Regulatory $\mathrm{T}$ cells and cancer. Curr Opin Immunol 19: 217-223, 2007.

23. Von Boehmer H: Mechanisms of suppression by suppressor T cells. Nat Immunol 6: 338-344, 2005.

24. Nielsen J, Holm TL and Claesson MH: $\mathrm{CD} 4{ }^{+} \mathrm{CD} 25^{+}$regulatory $\mathrm{T}$ cells: II. Origin, disease models and clinical aspects. APMIS 112: 642-650, 2004.

25. Valzasina B, Piconese S, Guiducci C and Colombo MP: Tumorinduced expansion of regulatory $\mathrm{T}$ cells by conversion of $\mathrm{CD} 4{ }^{+} \mathrm{CD} 25^{-}$lymphocytes is thymus and proliferation independent. Cancer Res 66: 4488-4495, 2006.

26. Thornton AM and Shevach EM: CD4 ${ }^{+} \mathrm{CD} 25^{+}$immunoregulatory $\mathrm{T}$ cells suppress polyclonal $\mathrm{T}$ cell activation in vitro by inhibiting interleukin 2 production. J Exp Med 188: 287-296, 1998.

27. Ghiringhelli F, Menard C, Martin F and Zitvogel L: The role of regulatory $\mathrm{T}$ cells in the control of natural killer cells: relevance during tumor progression. Immunol Rev 214: 229-238, 2006. 
28. Ralainirina N, Poli A, Michel T, Poos L, Andres E, Hentges F and Zimmer J: Control of natural killer (NK) cell functions by $\mathrm{CD} 4{ }^{+} \mathrm{CD} 25^{+}$regulatory T cells. J Leukoc Biol 81: 144-153, 2006.

29. Bluestone JA and Tang Q: How do $\mathrm{CD} 4{ }^{+} \mathrm{CD} 25^{+}$regulatory $\mathrm{T}$ cells control autoimmunity? Curr Opin Immunol 17: 638-642, 2005.

30. Pakravan N, Hassan AT and Hassan ZM: Naturally Occurring self-reactive $\mathrm{CD} 4(+) \mathrm{CD} 25(+)$ regulatory $\mathrm{T}$ cells: universal immune code. Cell Mol Immunol 4: 197-201, 2007.

31. Miller AM, Lundberg K, Ozenci V, Banham AH, Hellstrom M, Egevad L and Pisa P: CD4 ${ }^{+} \mathrm{CD} 25^{\text {high }} \mathrm{T}$ cells are enriched in the tumor and peripheral blood of prostate cancer patients. J Immunol 177: 7398-7405, 2006

32. Yang ZZ, Novak AJ, Stenson MJ, Witzig TE and Ansell SM: Intratumoral $\mathrm{CD}^{+} \mathrm{CD} 25^{+}$regulatory T-cell-mediated suppression of infiltrating CD4+ $\mathrm{T}$ cells in B-cell non-Hodgkin lymphoma. Blood 107: 3639-3646, 2006

33. Lau KM, Cheng SH, Lo KW, Lee SA, Woo JK, van Hasselt $\mathrm{CA}$, Lee SP, Rickinson $\mathrm{AB}$ and $\mathrm{Ng} \mathrm{MH}$ : Increase in circulating Foxp $3{ }^{+} \mathrm{CD} 4+\mathrm{CD} 25$ (high) regulatory $\mathrm{T}$ cells in nasopharyngeal carcinoma patients. Br J Cancer 96: 617-622, 2007.

34. Curiel TJ, Coukos G, Zou L, Alvarez X, Cheng P, Mottram P, Evdemon-Hogan M, Conejo-Garcia JR, Zhang L, Burow M, Zhu Y, Wei S, Kryczek I, Daniel B, Gordon A, Myers L, Lackner A, Disis ML, Knutson KL, Chen L and Zou W: Specific recruitment of regulatory $\mathrm{T}$ cells in ovarian carcinoma fosters immune privilege and predicts reduced survival. Nat Med 10: 942-949, 2004

35. Mizukami Y, Kono K, Kawaguchi Y, Akaike H, Kamimura K, Sugai $\mathrm{H}$ and Fujii H: CCL17 and CCL22 chemokines within tumor microenvironment are related to accumulation of Foxp3(+) regulatory T cells in gastric cancer. Int J Cancer 122: 2286-2293, 2008

36. Strauss L, Whiteside TL, Knights A, Bergmann C, Knuth A and Zippelius A: Selective survival of naturally occurring human $\mathrm{CD} 4{ }^{+} \mathrm{CD} 25^{+} \mathrm{Foxp}^{+}$regulatory $\mathrm{T}$ cells cultured with rapamycin. J Immunol 178: 320-329, 2007

37. Liu W, Putnam AL, Xu-Yu Z, Szot GL, Lee MR, Zhu S, Gottlieb PA, Kapranov P, Gingeras TR, Fazekas de St Groth B, Clayberger C, Soper DM, Ziegler SF and Bluestone JA: CD127 expression inversely correlates with FoxP3 and suppressive function of human CD4+ $\mathrm{T}$ reg cells. J Exp Med 203: 1701-1711, 2006.

38. Kawamata H, Nakashiro K, Uchida D, Harada K, Yoshida H and Sato M: Possible contribution of active MMP2 to lymphnode metastasis and secreted cathepsin $\mathrm{L}$ to bone invasion of newly established human oral-squamous-cancer cell lines. Int J Cancer 70: 120-127, 1997

39. Sozzani S, Luini W, Borsatti A, Polentarutti N, Zhou D Piemonti L, D'Amico G, Power CA, Wells TN, Gobbi M, Allavena P and Mantovani A: Receptor expression and responsiveness of human dendritic cells to a defined set of CC and CXC chemokines. J Immunol 159: 1993-2000, 1997.

40. Fujii-Maeda, S, Kajiwara K, Ikizawa K, Shinazawa M, Yu B Koga T, Furue M and Yanagihara Y: Reciprocal regulation of thymus and activation-regulated chemokine/macrophage-derived chemokine production by interleukin (IL)-4/IL-13 and interferongamma in HaCaT keratinocytes is mediated by alternations in E-cadherin distribution. J Invest Dermatol 122: 20-28, 2004.

41. Ziegler SF: FOXP3: not just for regulatory T cells anymore. Eur J Immunol 37: 21-23, 2007.

42. Purwar R, Werfel T and Wittmann M: IL-13-stimulated human keratinocytes preferentially attract $\mathrm{CD} 4{ }^{+} \mathrm{CCR} 4{ }^{+} \mathrm{T}$ cells: possible role in atopic dermatitis. J Invest Dermatol 126: 10431051,2006

43. Bonecchi R, Sozzani S, Stine JT, Luini W, D'Amico G, Allavena P, Chantry D and Mantovani A: Divergent effects of interleukin-4 and interferon-gamma on macrophage-derived chemokine production: an amplification circuit of polarized $\mathrm{T}$ helper 2 responses. Blood 92: 2668-2671, 1998.

44. Bergmann C, Strauss L, Wang Y, Szczepanski MJ, Lang S, Johnson JT and Whiteside TL: T regulatory type 1 cells in squamous cell carcinoma of the head and neck: mechanisms of suppression and expansion in advanced disease. Clin Cancer Res 14: 3706-3715, 2008.

45. Sato E, Olson SH, Ahn J, Bundy B, Nishikawa H, Qian F, Jungbluth AA, Frosina D, Gnjatic S, Ambrosone C, Kepner J, Odunsi T, Ritter G, Lele S, Chen Y, Ohtani H, Old LJ and Odunsi K: Intraepithelial CD8+ tumor-infiltrating lymphocytes and a high $\mathrm{CD}^{+} /$regulatory $\mathrm{T}$ cell ratio are associated with favorable prognosis in ovarian cancer. Proc Natl Acad Sci USA 102: 18538-18543, 2005.

46. Petersen RP, Campa MJ, Sperlazza J, Conlon D, Joshi MB, Harpole DH Jr and Patz EF Jr: Tumor infiltrating Foxp3+ regulatory $\mathrm{T}$ cells are associated with recurrence in pathologic stage I NSCLC patients. Cancer 107: 2866-2872, 2006.

47. Bates GJ, Fox SB, Han C, Leek RD, Garcia JF, Harris AL and Banham AH: Quantification of regulatory T cells enables the identification of high-risk breast cancer patients and those at risk of late relapse. J Clin Oncol 24: 5373-5380, 2006.

48. Hori S: Rethinking the molecular definition of regulatory $\mathrm{T}$ cells. Eur J Immunol 38: 928-930, 2008.

49. Schaefer C, Kim GG, Albers A, Hoermann K, Myers EN and Whiteside TL: Characteristics of $\mathrm{CD} 4{ }^{+} \mathrm{CD} 25^{+}$regulatory T cells in the peripheral circulation of patients with head and neck cancer. Br J Cancer 92: 913-920, 2005

50. D'Ambrosio D, Iellem A, Bonecchi R, Mazzeo D, Sozzani S, Mantovani A and Sinigaglia F: Selective up-regulation of chemokine receptors CCR4 and CCR8 upon activation of polarized human type 2 Th cells. J Immunol 161: 5111-5115, 1998.

51. Shimizu J, Yamazaki S, Takahashi T, Ishida Y and Sakaguchi S: Stimulation of CD25(+)CD4(+) regulatory T cells through GITR breaks immunological self-tolerance. Nat Immunol 3: 135-142, 2002.

52. Nocentini G, Ronchetti S, Cuzzocrea S and Riccardi C: GITR/GITRL: more than an effector T cell co-stimulatory system. Eur J Immunol 37: 1165-1169, 2007.

53. Nocentini G and Riccardi C: GITR: a multifaceted regulator of immunity belonging to the tumor necrosis factor receptor superfamily. Eur J Immunol 35: 1016-1022, 2005.

54. Ronchetti S, Zollo O, Bruscoli S, Agostini M, Bianchini R, Nocentini G, Ayroldi E and Riccardi C: GITR, a member of the TNF receptor superfamily, is costimulatory to mouse T lymphocyte subpopulations. Eur J Immunol 34: 613-622, 2004.

55. Vulcano M, Albanesi C, Stoppacciaro A, Bagnati R, D'Amico G, Struyf S, Transidico P, Bonecchi R, Del Prete A, Allavena P, Ruco LP, Chiabrando C, Girolomoni G, Mantovani A and Sozzani S: Dendritic cells as a major source of macrophagederived chemokine/CCL22 in vitro and in vivo. Eur J Immunol 31: 812-822, 2001

56. Bonecchi R, Bianchi G, Bordignon PP, D'Ambrosio D, Lang R, Borsatti A, Sozzani S, Allavena P, Gray PA, Mantovani A and Sinigaglia F: Differential expression of chemokine receptors and chemotactic responsiveness of type $1 \mathrm{~T}$ helper cells (Th1s) and Th2s. J Exp Med 187: 129-134, 1998.

57. Andrew DP, Chang MS, McNinch J, Wathen ST, Rihanek M, Tseng J, Spellberg JP and Elias CG 3rd: STCP-1 (MDC) CC chemokine acts specifically on chronically activated Th2 lymphocytes and is produced by monocytes on stimulation with Th2 cytokines IL-4 and IL-13. J Immunol 161: 5027-5038, 1998.

58. Echigo T, Hasegawa M, Shimada Y, Inaoki M, Takehara K and Sato S: Both Th1 and Th2 chemokines are elevated in sera of patients with autoimmune blistering diseases. Arch Dermatol Res 298: 38-45, 2006.

59. Mariani M, Lang R, Binda E, Panina-Bordignon $P$ and D'Ambrosio D: Dominance of CCL22 over CCL17 in induction of chemokine receptor CCR4 desensitization and internalization on human Th2 cells. Eur J Immunol 34: 231-240, 2004.

60. Jakubzick C, Wen H, Matsukawa A, Keller M, Kunkel SL and Hogaboam CM: Role of CCR4 ligands, CCL17 and CCL22, during Schistosoma mansoni egg-induced pulmonary granuloma formation in mice. Am J Pathol 165: 1211-1221, 2004.

61. Ishida $\mathrm{T}$ and Ueda R: CCR4 as a novel molecular target for immunotherapy of cancer. Cancer Sci 98: 1139-1146, 2006.

62. Yamashita U and Kuroda E: Regulation of macrophage-derived chemokine (MDC, CCL22) production. Crit Rev Immunol 22: 105-114, 2002

63. Pries R and Wollenberg B: Cytokines in head and neck cancer. Cytokine Growth Factor Rev 17: 141-146, 2006.

64. Pries R, Thiel A, Brocks C and Wollenberg B: Secretion of tumor-promoting and immune suppressive cytokines by cell lines of head and neck squamous cell carcinoma. In Vivo 20: 45-48, 2006. 